\title{
A HAZAI TERÜLETFEJLESZTÉSI GYAKORLAT NÉHÁNY KULCSPROBLÉMÁJÁRÓL ${ }^{1}$
}

\author{
(Fundamental Issues of the Practice of Regional Development \\ Policy in Hungary)
}

KISS JÁNOS

1996 márciusa, a területfejlesztésröl és a területrendezésröl szóló törvény megszületése óta lázas tevékenység folyik a magyarországi területfejlesztés új, "alulról építkezỏ és decentralizált" rendszerének gyakorlati megvalósítása érdekében. E "rendszerváltoztató" folyamatnak még csak a kezdetén tartunk, s a megtett lépések eddig jobbára csak a rendszer két elemének megteremtésére irányultak: az intézmény-alakitás és a fejlesztési koncepciók készitése jutott meghatározó - kissé talán túlságosan is hangsúlyos - szerephez.

Mindezek ellenére akad néhány általánosnak látszó, az ország különböző megyéiben-kistérségeiben egyaránt elöforduló, különböző fórumokon jórészt már megfogalmazott fontos probléma, amelyek számbavétele már ma is lehetségesnek látszik. Ezek egy része döntően a törvényi szabályozás fogyatékosságaira vezethető vissza, mások viszont kifejezetten a kialakult - számos "külső" hatást tükrözö területfejlesztési gyakorlat kritikájaként fogalmazhatók meg. A különbözö eredetủ problémák megvitatása és a megfelelő megoldási javaslatok kidolgozása sürgető szakmai feladat, hiszen a területfejlesztés új rendszerének megszilárdulása után vélhetőleg sokkal kisebb lehetőség lesz a korrekciók elvégzésére.

A következőkben a területfejlesztési koncepció-készités során szerzett saját tapasztalataim; illetve az általam megismert területi szereplök véleménye és a témával foglalkozó szakirodalom alapján, az általánositás igényével szeretném felhívni a figyelmet néhány - álláspontom szerint a területfejlesztés eredményességét nagymértékben korlátozó - szervezeti-strukturális zavarra.

Úgy tünik, hogy e vonatkozásokban a törvényben tapasztalható bizonytalan megfogalmazások, logikai következetlenségek, illetve egyes kérdések szabályozatlansága okozzák a legtöbb gondot. Nagyon sok konfliktus forrásai a részben a törvénnyel kapcsolatos politikai kompromisszumokat tükröző párhuzamosságok, funkciókettőződések. Így szó esik tervezési-statisztikai és funkcionális térkategóriákról, amelyek egymáshoz való viszonya és a területfejlesztési intézményrendszerben játszott szerepe egyaránt bizonytalan. (Ez különösen a kistérségek szervezödése szempontjából okoz nyilvánvaló zavarokat.)

Szintén párhuzamosságok tapasztalhatók a területfejlesztési illetve az önkormányzati intézményrendszerben. Ez elsősorban a megyei szinten - Megyei Közgyülés, illetve Megyei Területfejlesztési Tanács - okoz némiképp tudathasadásos helyzetet. Az a tény pedig, hogy a területfejlesztési tanácsok, illetve a kistérségi társulások munkaszervezete - részben a törvény által előirtan gyakorlatilag a megyei, illetve a telepủlési önkormányzatokhoz kötődik, legalább annyi hátrányt jelent a területfejlesztésben való társadalmi részvétel szempontjából, 
mint amennyi előnye van a müködtetés technikai-finanszírozási oldaláról nézve. Véleményem szerint megkérdőjelezhetö az Országos Területfejlesztési Központ, mint kormányszerv léte is: feladatát nyugodtan elláthatná a KTM Területfejlesztési Főosztálya.

A területfejlesztési koncepciókkal kapcsolatban nagy hiányosság - bár az ebböl eredő konfliktusok valószínüleg csak a jövőben fognak komoly gondokat okozni hogy nincs szabályozva a különbözö területi szintü koncepciók egymásra épülésének rendszere, így azok ma gyakorlatilag egymástól függetlenül, többékevésbé véletlenszerüen születnek meg. A helyes irány tekintetében - ti, hogy felülröl lefelé, vagy alulról fölfelé épüljenek egymásra a koncepciók - megoszlanak a vélemények. Magam az elöbbi megoldás híve vagyok, azaz: optimális esetben az Országos Területfejlesztési Koncepciónak kellene legelöször elkészülnie, s ennek ismeretében dolgozhatnák ki saját koncepcióikat a megyék, majd a kistérségek. Ez nem mond ellent az alulról építkező területfejlesztés elvének: az államnak természetesen a térségi szereplők véleményét meghallgatva - mindig "tudnia kell", hogy mit akar kezdeni az egyes régióival, $\mathrm{s}$ hogy e célok elérése érdekében milyen fejlesztéseket, miféle eszközökkel kíván támogatni. Az országos koncepció ismeretében pedig a kisebb területi egységek már úgy készithetik el saját koncepcióikat, hogy pontosan tudják: mely fejlesztési elképzeléseikhez számíthatnak központi területfejlesztési forrásokra, s melyekhez nem.

Jórészt a területfejlesztési törvényen kívüli okokkal magyarázható viszont a hazai területfejlesztési gyakorlat egy másik - véleményem szerint meghatározó problémája: az, hogy az általa érintett helyi szereplök jelentốs (nagyobbik?) részének nincs helyes, vagy nincs elégséges ismerete a piacgazdasági viszonyok között megvalósuló területfejlesztés lehetőségeiről, cél- és eszközrendszeréröl, és/vagy nincs megfelelő érdekeltsége az ennek megfelelö közremüködésre. Tapasztalataim szerint még ma is elterjedt attitüd az, amely központilag kitalált, kézzelfogható célok érdekében, településekre lebontott, "feluulröl" történő, s lehetőleg minél bőségesebb pénzosztást lát - vagy szeretne látni - elsősorban a területfejlesztésben. Ez a megfogalmazás persze erösen túlzó, de a benne szereplö elemek ma is hatnak, nehezitve a teruletfejlesztés új modelljének meghonosodását. Számos tényezỏ hat ebben az irányban:

- az államszocialista rendszerben a területfejlesztés fogalomköréhez érthető módon erősen hozzátapadt ez a jelentéstartalom, aminek megváltozása korántsem annyira magától értetődő, mint a politikai rendszerváltozás legtöbb jelensége esetében. Az új területi politika müködéséröl ráadásul csak esetlegesen kaptak információkat és magyarázatokat a helyi szereplök, s így gyakran túlbecsúlik lehetőségeit a spontán területi folyamatok alakítására;

- a demonstrativ fejlesztések politikai kényszere a helyi vezetök számára: az őket megválasztó lakosság számára a helyben megvalósuló, materiálisan létezö fejlesztések biztosíthatják legnyilvánvalóbb módon a legitimitást;

- a központi fejlesztési források elosztása még ma is meglehetősen centralizált, $\mathrm{s}$ így az egyes telepúlések és régiók akkor látják csak biztosítva saját fejlödésüket, ha egyértelmüen megnevezik azokat a fejlesztési tervekben;

- a területfejlesztés új modellje az előzőnél jóval nagyobb aktivitást és kreativitást kíván a helyi szereplőktől is. Számukra viszont sokkal 
egyszerübb "szegénynek nyilváníttatni" magukat és felülröl "várni" a terveket meg a pénzt, mint épkézláb, megvalósitható és hasznos dolgokat kitalálni, megvitatni, hozzájuk cselekvőképes helyi eröket megnyerni és forrásokat találni.

A települések és régiók - tőbbek között a törvényi szabályozásnak köszönhetően elsösorban egymás versenytársai: nincs komolyabb érdek és - egyelöre - nincs igazán kényszer sem az érdemi együttmüködésre. E megállapításnak nem mond ellent az a tény sem, hogy a törvény elfogadása óta eltelt időszakban sorra alakultak, és ma már szinte az ország teljes területét lefedik a kistérségi területfejlesztési önkormányzati társulások. Ezeknek a törvény kulcsszerepet szán, ami önmagában helyes, de épp az imént emlitett "együtt-nem-müködés" miatt a Megyei Területfejlesztési Tanácsok a kistérségek osztozkodásának terepévé váltak. Ez azért veszélyes jelenség, mert így nincs lehetőség megyei léptékü koncepciók kidolgozására, az egész megyét érintő stratégiai programok támogatására még az adott anyagi korlátok között sem, $s$ a beavatkozások lokalizálását a hatékonyság szempontja helyett sok esetben a kistérségek provinciális érdekharcainak pillanatnyi állása dönti el. A valódi egyưttmüködés szándékát viszont a közös célok érdekében történő kölcsönös lemondások jeleznék...

$\mathrm{Az}$ érdekegyeztetés effajta hiányosságai ugyanakkor a magukon a kistérségi társulásokon belül - a résztvevő települések között - is tapasztalhatók, ami számos további problémával van összefüggésben:

- a társulások nagyobb része a megyei területfejlesztési tanácsokban való formális képviselet, a társuláshoz kötött ad hoc jellegü pályázási és pénzszerzési lehetőségek elnyerésére alakult, $\mathrm{s}$ ma is csak ezek a tényezők kötik össze a résztvevő telepúléseket;

- egybeszervezödésük az esetek többségében nem, vagy nem csak a racionalitás és a közös érdekek mentén történt: abban politikai különbségek, a vezetök személyi ellentétei, korábbi vélt vagy valós sérelmek is szerepet játszottak;

- mindezek miatt a kistérségi társulások területe nem mindig feleltethetö meg bármiféle ténylegesen létező funkcionális kapcsolatrendszernek, vonzáskörzeti viszonynak, vagy akár hagyományos táji-történeti egybetartozásnak, identitásnak; emellett előfordulnak kettős, illetve hármas tagságú települések és területileg nem egybefüggő társulások is. Az ilyen esetekben elméletileg is meglehetősen nehéznek tünik bármiféle valódi együttmüködés, hatékony kistérség-fejlesztő program kidolgozása és megvalósítása;

- a kistérségi társulásokban nehezen találják helyüket a kedvezőbb mutatókkal rendelkezö nagyobb városok: "város és vidéke" együttmüködés helyett nagyon gyakran szembekerül egymással. Problematikus a sajátos településcsoportok (nagyfalvas rendszerek, agglomerálódó térségek) helyzete is. (A korábban létrejött, esetenként kifejezetten sikeresen müködő település szövetségeknek, térségfejlesztő egyesületeknek pedig komoly problémát jelentett a törvényi szabályozás, mert szervezeti formáik változtatás nélkül nem feleltek meg az új elöírásoknak, és így formális átalakulásra vagy egy újabb, az eredetivel párhuzamosan mükődő szervezet létrehozására kényszerültek.) 
Véleményem szerint azonban mégsem az eddig említett fogyatékosságok jelentik a kistérségi társulások - szélesebben értelmezve pedig az új területfejlesztési modell kistérségi szintje - eredményes müködésének legnagyobb akadályát. Strukturális szempontból jóval lényegesebb, hogy - a jószerével egy kézen összeszámolható pozitiv kivételektöl eltekintve - nem sikerült még elterjeszteni a területfejlesztés társadalmasitásának, a civil szféra bevonásának lehetöségeit és technikáit. Söt, a társulások jelenlegi vezetői általában nem is akarják megszólitani az embereket, s azt várják a helyi társadalmaktól, hogy legitimálják a döntéseiket.

$\mathrm{Az}$ alulról építkezö területfejlesztés modellje éppen a társadalmi részvételen alapul. Ezzel szemben a mai kistérségi társulások résztvevöi szinte kizárólag a települési önkormányzatok. Sarkosan fogalmazva: az esetek többségében "polgármesterek asztaltársaságairól" beszélhetünk csak. (Ezt bizonyítja több általam hallott, önkormányzati tisztségviselöktől származó megfogalmazás is: egy helyen "a kistérségeket alkotó polgármesterekröl" volt szó, míg egy másik község elsö embere azt mondta: egyszer polgármesterekként, máskor kistérségként gyülnek össze kollégáival...) E téves - ugyanakkor a tervezési gyakorlatban is nemegyszer kimutatható - szemlélet uralkodóvá válásában sajnos meghatározó szerepe van a területfejlesztési törvénynek is, amely a kistérségi szintü együttmüködés egyedüli lehetséges formájaként az önkormányzati társulást ismeri el, $\mathrm{s}$ így elvileg is kizárja az intézményes együttmüködésből a gazdasági vállalkozásokat, közintézményeket, civil szervezeteket és a magánszemélyeket - hogy csak a legfontosabb potenciális szereplöket említsük.

Az önkormányzati szférán kívüli társadalom bevonása persze igen nehéz feladat a mai Magyarországon, hiszen a civil társadalom megszervezödése tudvalévöleg igen alacsony fokon áll. A legeredményesebben müködő kistérségi szervezetek ugyanakkor éppen azzal tünnek ki a többi közül, hogy meg tudták szólitani a helyi lakosságot, valamint egyes civil szervezeteket, intézményeket és a vállalkozók egy részét is. Az eredmények egyelöre itt is elsösorban néhány lelkes, szinte megszállott lokálpatrióta és néhány hozzájuk csatlakozott szakértő áldozatos munkájának köszönhetök. Mindemellett a közösségszervező tevékenység széles körü elterjesztésére a térségfejlesztés professzionalizálódása nyújthat igazi lehetöséget. Ennek ma még csak a csírái látszanak: a szakértö és elkötelezett térségmenedzserek hálózata, a gyakorlatiasan müködő kistérségi fejlesztési irodák jelenthetik talán a jövő útját ezen a téren.

$\mathrm{Az}$ eddig említett problémák közepette a jelenlegi helyzetben különösen nagy jelentősége van a területfejlesztési koncepciók készitésének. Ezeket ugyanis olyan területfejlesztési szakemberek készítik, akik a megrendelök többségéhez képest sokkal inkább ismerik az alulról építkezö területfejlesztési modell lehetöségeit, alapelveit és eszközrendszerét, ugyanakkor folyamatos kapcsolatban kell állniuk a koncepciókat és konkrét fejlesztési programokat majdan megvalósító térségi szereplökkel. E kommunikációs folyamat - mely megitélésem szerint a tervezés lényegi eleme - kedvezỏ lehetőséget kinál a területfejlesztési rendszer egyes elemeivel kapcsolatos félreértések tisztázására; a célok, feladatok, eszközök és korlátok megismertetésére és elkülönítésére az érintett helyi társadalmi csoportok számára. 
A helyi törekvéseknek az új modell keretei közé történő beillesztése ugyanis csak akkor lehetséges, ha a megrendelök is tisztában vannak vele: a területfejlesztés csupán arra vállalkozhat, hogy a kevés közcélú forrást az általa meghatározott prioritásokra irányitsa, a civil társadalmat és a piaci szférát pedig megkisérelje csatlakoztatni hozzájuk. Ebböl a kiindulópontból egyértelmũen következik a koncepciókészités valódi szerepe is: a területi szereplök szándékait megismerve reális fejlesztési lehetôségeket feltárni számukra, a megvalósitás terheinek és a várható következmények minél szélesebb körének bemutatásával együtt.

A fenti érvelés alapján a továbbiakban az eddig elkészült megyei és kistérségi koncepciókkal kapcsolatos néhány vitás kérdésben szeretnék állást foglalni, illetve egyes problémákat kiemelni.

Többen is felhívták már a figyelmet arra a jelenségre, hogy az elkészült tervezetek jelentös része "kívánságlistára", ágazati "ötletgyüjteményre" hasonlit. Ezek a társadalmi részvétel lehetőségének és a megvalósítás kérdéseinek alapos tárgyalása nélkül nem tekinthetők valódi koncepciónak, stratégiai tervnek. E tényre újból és újból fel kell hivni a figyelmet, mert alkalmanként szakmai körökben is hallani azt a megközelítést, melynek értelmében nem szükséges a kívánságok, ötletek megvalósithatóságának vizsgálata, az ennek alapján történö szelektálás, mondván: a helyi szereplök igényei, meg a finanszírozási korlátok "úgyis" elvégzik ezt maguktól. Ez az álláspont véleményem szerint a területfejlesztés szakmai jellegét kérdőjelezi meg: ótletek ősszegyüjtéshez nem kell különösebb képzettség - a szakma szerepe és felelőssége éppen az ezen túlmenő kérdésekben (széleskörü információszerzés, célmeghatározás, stratégiakészités, megvalósithatósági szempontok, prognózis stb., majd mindezek alapján a kínálkozó lehetôségek közötti választás javaslata) rejlik.

Nagyon sok az általánosan elterjedt, "divatos" fejlesztési elképzelés az ismert koncepciók többségében. Az olyan "varázsszavak", mint a vállalkozói òvezet, ipari park, innovációs centrum, logisztikai központ, repülötér, falusi turizmus, imázsjavitás persze a megrendelök politikai igényeit, csodavárását is tūkrözik. Ám a koncepciókban való differenciálatlan szerepeltetésük azt is jelzi, hogy a szakma nem mindig vállalja fel megrendelō̉ ezekkel kapcsolatos informálását, az esetleges konfliktusokat, $\mathrm{s}$ a könnyebb ellenálás irányába mozdulva szerepelteti öket a helyi sajátosságoknak jobban megfelelö egyedi elképzelések megfogalmazásával szemben.

A szakmai fórumok szintjén már többször megfogalmazódott, de a koncepciókészitésben még nem kellöen tükrözödik az utóbbi évek terulletfejlesztési gyakorlatával kapcsolatos azon felismerés, hogy az infrastruktúra - különösen a helyi infrastruktúra - fejlesztése önmagában nem hoz érdemi gazdasági fejlődést, $\mathrm{s}$ nem képes a felemelkedés alapjává válni az elmaradott térségekben. A területi fejlődés kulcsát jelentő gazdasági élénkưlés megindulásához (a külső tökebevonáson túl) valószínüleg egyéb fejlesztési irányok - mint a helyi munkaerőképzés, a kommunikációs hálózatok kiépitése, a helyi kutatóbázisok támogatása, nemzetközi integrálódás, stb. - megfelelő kombinációi teremthetik meg az alapokat.

A kistérségi fejlesztési tervek kidolgozásánál sajátos problémát jelent a térségek mérete: a gazdasági fejlesztések optimális piacmérete meghaladja a kistérségek 
tőbbségének nagyságát, s nem elégséges mértékủ a helyi tőkeképződés sem. A társadalom megszólítása viszont éppen a kisebb egységek szintjén hatékony.

Jelentős differenciák mutatkoznak - s igy eltérő megkőzelítésekre van szükség - a fejlettebb és az elmaradottabb régiók fejlesztésében: az utóbbi területeken általában nagyobb a hajlandóság az összefogásra, ám kevesebb a kínálkozó jó lehetőség, illetve az ezekhez rendelhető anyagi és emberi eröforrás. Ettől függöen mindenütt más típusú és más léptékü programok kellenek: a fejlettebb területeken nagyobb hangsúlyt kell fektetni egyfajta sajátos marketing tevékenységre, a megvalósításra jelentkező piaci vállalkozók orientálására, míg a hátrányos helyzetủ térségekben - a külső forrásszerzés elsődlegességén túl - szükségképpen nagyobb súlyt kell kapniuk az öneröből megoldható, közösségi együttmüködésen alapuló kisebb volumenü fejlesztési javaslatoknak.

A koncepciókészités során a jelenleginél nagyobb figyelmet kell fordítani, egyrészt a koncepció "müködtetésének" eszközeire, másrészt a források elosztásának néhány - a fejlesztési prioritásokon túlmenő - elvi kérdését is szabályozni kellene.

Véleményem szerint a hazai területfejlesztés legnagyobb problémája ma még az ilyen célokra fordítható források szükössége. Épp azért kell azonban a szervezetistrukturális problémákat mielöbb tisztázni és megoldani, hogy amikor remélhetőleg a nem túl távoli jövőben - a jelenleginél lényegesen több pénz fog jutni a területfejlesztésre, azt minél hatékonyabban lehessen majd felhasználni.

\section{Jegyzetek}

${ }^{1}$ Az előadás $A$ területi tervezés új kihívása: a területfejlesztési koncepció c. konferencián hangzott el. (Győr, 1997. április 3-4.) 